DOI: 10.17951/lrp.2019.38.3.285-296

\author{
ZoFia RemiszewsKa \\ Uniwersytet Opolski, Wydział Nauk Społecznych, \\ Instytut Nauk Pedagogicznych, Katedra Teoretycznych Podstaw Edukacji i Wychowania \\ ORCID - 0000-0002-9995-0203
}

\title{
REKONSTRUKCJA PAMIĘCI DOMU RODZINNEGO A ŹRÓDŁA ZAINTERESOWAŃ ZADANIAMI PONADOSOBISTYMI
}

\begin{abstract}
Streszczenie: W artykule wykorzystałam fragmenty moich badań, przygotowanych na podstawie wywiadów narracyjnych. Główny przyjęty przeze mnie problem badawczy sformułowałam $\mathrm{w}$ formie pytania: jakie znaczenie ma rodzina w kształtowaniu postaw prospołecznych u tych osób, które realizują zadania ponadosobiste? Poszukuję również odpowiedzi na pytanie: czy w biografii własnej i rodziny można odnaleźć źródła zainteresowania problematyką społeczną? Dzięki zastosowaniu wywiadów narracyjnych mogłam zrozumieć elementy rzeczywistości badanych. Mogłam dokonać wglądu w źródła i doświadczenia związane z realizacją zadań ponadosobistych badanych osób. Ich subiektywne interpretacje swoich zachowań, przeżyć związanych z różnymi sytuacjami, osobami, wydarzeniami, dały obraz znaczenia rodziny $\mathrm{w}$ formowaniu postaw prospołecznych.
\end{abstract}

Słowa kluczowe: dom rodzinny, pamięć dzieciństwa, prospołeczność, zadania ponadosobiste

\section{WPROWADZENIE}

W procesie przekazywania pamięci przeszłości rodzina odgrywa szczególną rolę. W niej przekazywane jest dziedzictwo kulturowe: poczucie więzi genealogicznej, zwyczaje, obyczaje, wzory zachowań, normy postępowania, wartości czy też przekonania. Na pytania: czym jest rodzina? jaka jest jej wartość w życiu człowieka? - w literaturze przedmiotu można doszukać się wielu odpowiedzi. Rodzina jest przede wszystkim grupą społeczną, środowiskiem wychowawczym, jest instytucją wychowania i wspólnotą osób (Izdebska 2016, s. 958). Członkowie rodziny stanowią swoistą grupę, w której zachowanie jednej osoby ma wpływ 
na pozostałych (Świętochowski 2017, s. 26). Rodzina umożliwia nam odbieranie osobistych doświadczeń oraz tych, które ujawniane są przez rodziców i innych członków rodziny. Stanowi system, który znajduje się w procesie ciągłego rozwoju. Rodzina jako system może być definiowana za pomocą dwóch wymiarów: struktury i zadań. Organizacja strukturalna to zestaw reguł rządzących wzorami interakcji, które zachodzą w granicach systemu rodzinnego. Natomiast zadania czy funkcje rodziny koncentrują się na jej wspólnych i istotnych obowiązkach. W tym systemie, w którym tkwi rodzina, bez względu na liczbę członków, określa ona swoją tożsamość, postrzeganą zarówno jako całość, jak i tożsamość każdego jej członka. Tu jasno zdefiniowane są granice między rodziną a światem zewnętrznym oraz poszczególnymi członkami w granicach rodziny. Rodzina określa strategię zarządzania domem, zasobami materialnymi (finanse), stresem oraz sposoby rozwiązywania konfliktów (Plopa 2015, s. 9-19).

Spoglądając na rodzinę jako na grupę zwłaszcza wychowawczą, ujmujemy rodzinę jako tę, która realizuje na podłożu zarówno aktywności spontanicznej (naturalnej, życiowej), jak i działalności organizacyjnej (intencjonalnej, przemyślanej, zaplanowanej) swoje cele i zadania (Kawula, Janke 2014, s. 30-31).

Wychowanie w domu rodzinnym sprzyja doświadczaniu siebie i świata czy też osiąganiu dobra wspólnego, ale zarazem dobra osobistego. Taki proces wychowania rodzinnego może sprzyjać ukierunkowaniu na rozwijanie zainteresowań zadaniami ponadosobistymi, co w konsekwencji sprzyja temu, by te zadania realizować.

Zadania ponadosobiste, które są głównym przedmiotem moich rozważań, budują związki integrujące człowieka ze światem, gratyfikują zarówno osobiste interesy podmiotu, jak i wizje świata możliwego i/lub pożądanego. Uważam, że dzięki realizacji zadań ponadosobistych młodzi mogą nadać swojemu życiu sens i wartość. Wpływają one na rozwój osobowości młodego człowieka, zwłaszcza gdy optymalizują stosunek człowiek - świat oraz stają się źródłem maksymalizacji szans na dalsze zmiany w osobowości (Łukaszewski 1984, s. 273). Przez zadania ponadosobiste rozwój osobowości jest motywowany zewnętrznie i wewnętrznie - w ramach poczynań jednostki - ukierunkowany na modyfikację stanów rzeczy poza własnym Ja, co prowadzi do zmian w świecie i zarazem we własnej osobie. Młodzi dzięki zadaniom ponadosobistym stają się bardziej otwarci, dynamiczni, wzbogacają siebie o nowe doświadczenia, a ich osobowość poddana jest niekończącym się procesom wzrostowym.

Niniejsze rozważania stanowią opracowanie fragmentu moich badań, przygotowanego na podstawie wywiadów narracyjnych „Projekty/zadania ponadosobiste w sferze publicznej w perspektywie autonarracyjnej drogi życia”. Badania przeprowadziłam w latach 2015-2017 i objęłam nimi 10 osób już realizujących zadania ponadosobiste. Wiek badanych osób oscylował w przedziale od 19 do 35 lat (okres dorastania i wczesnej dorosłości). 
Przyjęty przeze mnie główny problem badawczy sformułowałam w formie pytania: jakie znaczenie ma rodzina $\mathrm{w}$ kształtowaniu postaw prospołecznych $\mathrm{u}$ tych osób, które realizują zadania ponadosobiste? Poszukuję również odpowiedzi na pytanie: czy w biografii własnej i rodziny można odnaleźć źródła zainteresowania problematyką społeczną? Dzięki zastosowaniu wywiadów narracyjnych mogłam zrozumieć elementy rzeczywistości badanych. Mogłam dokonać wglądu w źródła i doświadczenie związane z realizacją zadań ponadosobistych badanych osób, docierając do ich pamięci autobiograficznej, do ich indywidualnych doświadczeń życiowych jako ciągu zdarzeń tworzących swoistą, historię życia. Pamięć autobiograficzna stanowi podstawę tworzenia doświadczenia dotyczącego własnej osoby, a także doświadczenia dotyczącego świata zewnętrznego oraz własnych relacji ze światem zewnętrznym (Maruszewski 2000, s. 165-175). „Pamięć może być traktowana zarówno jako pewna zdolność, którą w różnym stopniu odznaczają się różni ludzie, jak i jako proces, który ma pewne uniwersalne właściwości, analogiczne u różnych ludzi. Oba te ujęcia pamięci wzajemnie się uzupełniają, ponieważ stanowią alternatywne podejście do tego samego zjawiska. Gdy mówimy o pamięci jako pewnej strukturze, możemy zastanowić się nad tym, jakie są jej elementy składowe, jakie są jej odmiany. Gdy traktujemy pamięć jako proces - jako coś, co jest rozciągnięte w czasie - koncentrujemy się na fazach tego procesu, ich kolejności czy ewentualnie zachodzeniu na siebie" (Niedźwieńska 2018, s. 419).

Możemy wyróżnić pamięć deklaratywną, która dotyczy wiedzy przechowywanej w umyśle; rozgranicza się ona na dwa podsystemy: pamięć semantyczną (magazynującą znaczenie słów, koncepcji i wiedzę o świecie) i epizodyczną (wspomnienia o zdarzeniach z określeniem ich czasu, przestrzeni, okoliczności) (Modrak 2016, s. 7). Pamięć składa się z wielu faz. W pierwszej fazie zapisuje się materiał, który później jest przechowywany, a w końcu odtwarzany (Maruszewski 2017, s. 133). W moich rozważaniach definicję pamięci przyjmuję za Olgą Czerniawską, która skupia się na pamięci jako na procesie regulowania aktualnego zachowania pod wpływem dawnych doświadczeń własnych oraz funkcji pamięci: przechowywania, przypominania i przeżywania owych doświadczeń, dzięki którym jednostka może tworzyć czy odtwarzać własną historię życia (Czerniawska 2000, s. 90-91). Pamięć autobiograficzna zawiera też w sobie obraz naszego dzieciństwa - to pamięć m.in. rodziny i szkoły.

\section{DOM RODZINNY - JAK SIĘ GO ZAPAMIĘTAŁO?}

W pytaniach o wspomnienia z dzieciństwa mamy na myśli dom rodzinny i skojarzenia z nim związane. Wspomnienia pamięci domu rodzinnego to wspomnienia o warunkach życia. To wspomnienia o domownikach i ich wzajemnych relacjach. 
To wspomnienia o zwyczajach, tradycjach, symbolach i pamiątkach, sekretach, które kształtują swoisty sposób myślenia i odczuwania. Rodzina jest naturalnym środowiskiem wychowawczym (Łobocki 2010, s. 298), stanowi przestrzeń, w obrębie której dokonuje się wychowanie. Źródłem owego wychowania jest nie tylko wspólne życie, ale przede wszystkim atmosfera miłości, która stanowi podstawę do prawidłowego funkcjonowania rodziny. Efektywność wychowania w rodzinie zależy szczególnie od zespołu warunków określonych jako kultura rodzinna, wśród których można wyróżnić trzy kategorie: kulturę materialną rodziny, kulturę pedagogiczną rodziców oraz kulturę duchową rodziny (Kułaczkowski 2010, s. 187-196). Kultura materialna rodziny rozumiana jest jako warunki bytowe, dom, finanse. Kultura pedagogiczna rodziców przejawia się jako postawy rodzicielskie, role rodzicielskie, wiedza i świadomość celów wychowania oraz umiejętność stosowania środków pedagogicznych. Kultura duchowa rodziny to z kolei wartości i normy, wzory zachowań, wierzenia i zwyczaje, język, historia. Te kategorie będą stanowiły przedmiot moich rozważań.

\subsection{KULTURA MATERIALNA RODZINY}

Poniżej przytaczam fragmenty wywiadów narracyjnych dotyczące pamięci domu rodzinnego, których treści nawiązują do kategorii kultury materialnej rodziny.

\section{Dorota:}

Wspomnienia z dzieciństwa to przede wszystkim jest bieda, ponieważ mieszkaliśmy w biedniejszym rejonie Dolnego Śląska, gdzie w gruncie rzeczy jest patologia w postaci alkoholizmu, no i skrajnej biedy [...]. Mieszkaliśmy w dwupokojowym mieszkaniu we czworo. Ojciec większość czasu - od sześciu do dziesięciu miesięcy - przebywał za granicą. Przez długi czas zarobki rodziców oscylowały poniżej przeciętnej krajowej. Byli bardzo zapracowani.

Ewelina:

Dom rodzinny u babci - mieszkaliśmy tam z mamą, dzieciństwo mieliśmy ciepłe, skromne, jak to bywało w Polsce lat osiemdziesiątych. Utrzymywała mnie mama z pomocą babci oraz małych alimentów od taty (płaconych nieregularnie).

Ala:

Dzieciństwo pamiętam jako czas, gdy pod względem materialnym niczego w naszej rodzinie nie brakowało, a jeżeli były jakieś kłopoty, to rodzice zatrzymywali je i roz- 
wiązywali między sobą. W domu (przy którym było gospodarstwo) mieszkała nas szóstka: brat, mama, tata, babcia, dziadek i ja.

W świetle wywiadów kultura materialna rodzin badanych znalazła swój wyraz przede wszystkim w opisie domu, miejsca zamieszkania i warunków materialnych. Dom jest symbolem tego wszystkiego, co wiąże się z odrębnością, z faktem posiadania. Może odgrywać także rolę symboliczną, a przez to kulturotwórczą, stając się przy tym wyznacznikiem tego, co ludziom bliskie. Dom spełnia wielorakie funkcje: zabezpiecza życie i egzystencję materialną; zapewnia intymność życia rodzinnego; daje możliwość odpoczynku; jest miejscem kształtowania atmosfery rodzinnej, przekazywania uczuć; w nim tworzy się język rodzinny właściwy każdej rodzinie; to miejsce, które urządzamy według własnego upodobania; to miejsce sprawowania praktyk religijnych (Kułaczkowski 2010, s. 193). Na ogół dom jest symbolem bezpieczeństwa, choć niekoniecznie potwierdza się to w rzeczywistości, a także w przeprowadzonych przeze mnie badaniach. Dom determinuje warunki bytowe, które wraz z warunkami finansowymi wpływają na funkcjonowanie rodziny. Warunki finansowe, ekonomiczne tworzą tło codziennej egzystencji, pozwalają rodzinie funkcjonować, umożliwiają zaspokajanie potrzeb kulturalnych. Istnieje związek pomiędzy tymi czynnikami i wychowaniem. Ponadto w prawidłowym procesie wychowania ważne jest kształtowanie świadomości zdobywania dóbr materialnych i posługiwania się nimi. Problem zdobycia środków do życia jest zasadniczy, ale nie powinien stanowić celu samego w sobie. Sfera ekonomiczna jest ważna, ale nie powinna rekompensować deficytów miłości rodzicielskiej.

\subsection{KULTURA PEDAGOGICZNA RODZICÓW}

Poniżej przytaczam fragmenty wywiadów narracyjnych dotyczące pamięci domu rodzinnego, których treści nawiązują do kategorii kultury pedagogicznej rodziców.

\section{Dorota:}

Z siostrą nieustannie się kłóciłam. [...] Raczej byłam osobą wycofaną, mocno ukierunkowaną przez rodziców, aby coś w życiu osiągnąć. [...] Rodzice wysłali, kazali wręcz pójść do dobrego liceum - bogate dzieci, zupełnie inna rzeczywistość. [...] Tata wyjeżdżał do Rosji, do Niemiec, do Austrii, do Anglii, do Francji, wszędzie po prostu, żeby utrzymać rodzinę, przez co też stosunkowo rzadko bywał w domu, może raz na pół roku. 
Ewelina:

Mama przykładała wagę do kultury, edukacji, konwenansów i dobrego zachowania. Nie wolno było broić, zadawać się z urwisami albo z podejrzanymi typami z długimi włosami, którzy jednocześnie mnie pociągali (towarzystwo artystów, ludzie alternatywnie żyjący) i którzy nie zdobywali serca mamy. [...] Od strony podwórka mieszkały dzieci z biedniejszych i często patologicznych rodzin - raczej się z nimi nie bawiliśmy, mama tam mnie nie puszczała, ale jedna dziewczynka przychodziła do nas się bawić. [...] Było to dzieciństwo pełne barwnych chwil nad jeziorem $\mathrm{z}$ babcią, nad morzem z mamą.

Ala:

Postrzegam moją rodzinę jako niepewną, gdzie nie było za wiele bezpieczeństwa i w sumie nie można było się oprzeć tak naprawdę ani na mamie, ani na tacie. I był w niej w ogóle jakiś chaos, jakieś pomieszanie. [...] Moja rodzina była chyba takim negatywnym motywatorem. [...] Bałam się rozmawiać z rodzicami - nie wiem, nie chciałam im przeszkadzać, nie za bardzo ich wtajemniczałam w to, co się dzieje u mnie. Właściwie byłam zdana jakby na siebie i właśnie na podejmowanie jakichś decyzji, bo nie chciałam ich konsultować z rodzicami.

Z wywiadów przeprowadzonych z badanymi przytaczam powyżej te wątki, z których można odczytać konteksty pedagogiczne rodziny. Możemy tu zauważyć różne kategorie rodzin: od rodziny autokratycznej po rodzinę bezwładną (Kułaczkowski 2010, s. 188-189). Rodzinę Doroty postrzegam jako rodzinę z elementami autokratycznymi, gdzie w sposób autorytarny była ona mocno ukierunkowana przez rodziców (np. nakaz wyboru szkoły średniej). Obowiązywała w niej konwencja narzucania dziecku woli i decyzji rodzica. W rodzinie Eweliny dominowała z kolei postawa przesadnej opiekuńczości i ochraniająca, co wyrażało się w całkowitej zależności od rodzica. Dotyczyło to np. selekcji dzieci, z którymi można było się bawić, gdzie kryterium był status społeczny i ekonomiczny. Choć panowała tam atmosfera dobrego zachowania, zgodnego z rygorystycznym przestrzeganiem zasad i norm, to jednak była ona niejako wymuszana w sposób autorytarny. Natomiast przypadkowość i bezwład, brak poczucia bezpieczeństwa to swoiste cechy rodziny bezwładnej. Te cechy możemy zauważyć w rodzinie Ali. Brak zrozumienia ze strony rodziców nie ułatwiał rozwiązywania pojawiających się u Ali problemów, a taka sytuacja pozbawiała ją motywacji do wszelkich działań.

W przytoczonych powyżej fragmentach narracji zwraca uwagę fakt, że we wspomnieniach z dzieciństwa brakuje opisu stereotypowych sposobów zabaw, 
a przecież poprzez zabawy dziecko rozwija umiejętność współpracy w grupie, kooperacji oraz swój sposób myślenia. Są one naturalne dla tego okresu życia. Brak też informacji na temat zabawy z rodzicami.

\subsection{KULTURA DUCHOWA RODZINY}

Poniżej przytaczam fragmenty wywiadów narracyjnych dotyczące pamięci domu rodzinnego, których treści nawiązują do kategorii kultury duchowej rodziny.

\section{Dorota:}

W domu nie kultywowało się żadnych tradycji. Tata [...] od moich najmłodszych lat pracował za granicą, żeby jakoś utrzymać rodzinę. [...] Mama pracowała jako pielęgniarka. Gdy mama była w pracy na „dwunastki” (na dwanaście godzin), taty nie było w domu, no to jednak trzeba było umieć rozpalić w piecu, trzeba było umieć posprzątać, trzeba było umieć gotować, trzeba było umieć zająć się tym wszystkim.

\section{Ewelina:}

Mama wprowadzała mnie w towarzystwo ciekawych ludzi z pasjami, często gościli u nas w domu (intelektualiści, podróżnicy, społecznicy, malarze, lekarze, ale też zwykli ludzie, z którymi mama się przyjaźniła). [...] Mimo przeszkód staram się dążyć do celów. Chyba mam to w genach. Dobrze, że były w rodzinie takie silne kobiety: babcia, która doświadczyła wojny, i ta cała jej droga z Wołynia na Ziemie Odzyskane, a potem mama, która sama mnie wychowywała i też przeprowadzała się kilkakrotnie, i jakoś się osiedliła, i bardzo ustabilizowała, i to nie w takich czasach wyemancypowanych, jakie mamy teraz.

\section{Ala:}

Rodziców widzę jako odmienne osobowości - mama małomówna, wrażliwa, często nerwowa, domatorka; tata ekstrawertyczny, gadatliwy, dusza towarzystwa, często poza domem. [...] Mam takie odczucia, że właściwie od zawsze moja rodzina jest jakby zdeterminowana, powiedzmy, nałogiem alkoholowym mojego taty. I pamiętam też, że chociaż tata sprawiał problemy - tak kolokwialnie mówiąc - to jednak ja byłam bardzo z nim związana. Bardzo go lubiłam, bardzo go kochałam i pamiętam, że bardzo cierpiałam, kiedy wracał nietrzeźwy do domu, no i starałam się go bronić. I to było takie trochę śmieszne, no bo mała dziewczynka staje między rodzicami, mama jest 
zła i gotowa, żeby tatę wyrzucić z domu, no i ja właśnie wkraczałam w rolę obrońcy taty. I ja byłam raczej córką taty, a mój brat był synkiem mamy i właśnie tak się podzieliliśmy. I pamiętam ten mój stosunek do taty, że ja jestem jego obrończynią. [...] I pamiętam też, że póki żyła moja babcia, to razem z moim bratem najczęściej do niej biegliśmy i tam się u niej chroniliśmy i chowaliśmy. Ona była taką osobą, że potrafiła powiedzieć wyraźnie na przykład „kocham cię”, a rodzice tego nigdy nie robili.

Z wywiadów przeprowadzonych z badanymi przytaczam powyżej te wątki, z których można odczytać konteksty duchowe rodziny. Wartości i normy przekazywane przez rodziców są nośnikiem obyczajów. Wartości są swoistą busolą, nadają sens życiu. Wartości, normy, zwyczaje stanowią rdzeń kultury każdej grupy czy społeczeństwa, są przekazywane z pokolenia na pokolenie. Rola rodziny w przekazywaniu norm i zwyczajów jest pierwszoplanowa i najważniejsza, a to rzutuje na całokształt życia jednostki, jej tożsamości. To, co czynimy, jak się zachowujemy, jest zdeterminowane w dużej mierze przez naszych rodziców. Na podstawie wywiadów można zaobserwować, że w pewnych rodzinach kultywowanie pozytywnych wartości i norm było ważne (np. w przypadku Eweliny), ale zdarzały się też takie rodziny, w których nie było prawidłowego systemu budowania wartości (np. w przypadku Ali).

W rodzinie Eweliny istotne było otaczanie się ludźmi z pasją, którzy potrafili „zarażać” swoimi zainteresowaniami i od których emanowało wielkie zamiłowanie do tego, czym się zajmowali (np. podróżowanie, działania społeczne, artystyczne). Obcowanie z ludźmi z pasją stanowiło wzór zachowania. Przekaz wartości pozytywnych odgrywał doniosłą rolę, wyposażał badanych w swoisty system, do którego mogli odwoływać się później w dorosłym życiu. Dominowały takie wartości jak: piękno, wiedza, mądrość, przyjaźń, praca, zaradność, majątek, pieniądze - te wartości ukierunkowywały badanych, stanowiły fundament kształtowania się ich sylwetki. Źródło wzorów i norm zachowań dla Eweliny to hart ducha, konsekwencja, wytrwałość w działaniu, przekazywane przez jej mamę i babcię, a dla Doroty pracowitość, doświadczanie atmosfery pracy przekazywane przez jej rodziców.

W wypowiedziach badanych brakowało wspomnień o jakichkolwiek obyczajach czy tradycjach rodzinnych.

\section{2. ŹRÓDŁA ZAINTERESOWANIA ZADANIAMI PONADOSOBISTYMI}

Źródeł zainteresowania zadaniami ponadosobistymi może być wiele. Można odnaleźć je np. w rodzinie, szkole, środowisku społecznym. Dzięki zadaniom ponadosobistym mamy możliwość aktywnej realizacji własnej tożsamości, własnego 
Ja i działań prospołecznych. Tak więc realizacja zadań ponadosobistych niesie wiele dobrego dla osoby podejmującej owe zadania i jednocześnie niesie korzyści dla innych. Ta korzyść dla innych to działania prospołeczne, które wpisane są w zadania ponadosobiste.

Pierwsze zalążki prospołeczności możemy odnaleźć w rodzinie, która jest naturalnym środowiskiem wychowawczym. W niej rodzice uczą zachowań prospołecznych w procesie np. modelowania, naśladownictwa. Powoduje to efektywne rozwijanie, pogłębianie zachowań czy postaw społecznych i moralnie pożądanych (np. sposoby reagowania na potrzeby innych, wiedza o normach postępowania).

Poniżej przytaczam fragmenty wywiadów narracyjnych dotyczące źródeł zainteresowania działaniami prospołecznymi.

\section{Dorota:}

Dlaczego udzielam się społecznie [...]? Podejrzewam, że bierze się to z dzieciństwa, z tych dysproporcji, z tych rozbieżności. To, że się wychowało w biednej miejscowości, niezbyt bogatej rodzinie, później się trafia do liceum, gdzie są córki prezydentów, burmistrzów, potentatów, lekarzy, prawników, i widzi się taki duży przeskok, a te młode osoby, mające zaledwie szesnaście lat, uważają się na panów świata, patrzą z góry na osobę, która tak naprawdę nie dostała niczego na tacy. Jak patrzyłam na to wszystko z boku, to uważałam, że tak nie powinno być. Wszyscy mamy takie same prawa do kultury, do równego traktowania, do edukacji, nie jest to oczywista oczywistość, życie to weryfikuje - można chcieć, można nie dostać. Jak się ma pieniądze, to się ma o wiele większe możliwości. A działania społeczne dają - takie może urojone - poczucie, że można próbować coś zmienić i czasami ten efekt faktycznie jest widoczny, a czasami nie.

Ewelina:

Mama była taką pierwszą osobą, bo mama prowadziła dużo wyjazdów dla dzieci - na przykład jak byliśmy w podstawówce, to moja mama zabierała nas w lecie do Zakopanego i do Krakowa. W Krakowie było kilka dni przeznaczonych na kontakt z kulturą, a w Zakopanem wędrowaliśmy po górach. I to tak kilka razy jeździliśmy. Byliśmy również nad morzem, też z zieloną szkołą. I wiedziałam na przykład, że wakacyjny wyjazd to jest po prostu wolna inicjatywa mojej mamy. I to mi się gdzieś tak utrwaliło. I wiedziałam, że to dobrze wpływa na te dzieci, które z mamą jeździły. Był też taki nauczyciel z geografii i chyba historii, który prowadził Rajdy Spadającego Liścia i wyjazdy Bractwa Flanelowych Koszul. 
Ala:

Moja rodzina była chyba takim negatywnym motywatorem. [...] Jeśli chodzi o tę pozytywną motywację, to myślę, że kościół był właśnie takim miejscem. Kiedy zaczęłam chodzić do liceum, starsza koleżanka zaprowadziła mnie kiedyś na spotkania duszpasterstwa młodzieżowego. [...] I wtedy już właśnie organizowaliśmy jakieś takie wydarzenia, takie - powiedzmy - wolontarystyczne. [...] W moim liceum też zawiązała się taka grupa wolontariuszy i dołączyłam do tej grupy. [...] Chwilę też chodziłam do PCK, do Polskiego Czerwonego Krzyża.

W narracjach rozmówców na temat zainteresowań działaniami prospołecznymi można wyodrębnić charakterystyczne wątki, odmienne dla każdego $\mathrm{z}$ badanych.

Wątek rodziny z elementami autokratycznymi (Dorota). Generatorem zainteresowań postawami prospołecznymi była chęć „ucieczki” od patologii środowiska lokalnego, w którym panowały bieda i wykluczenie społeczne, będące wynikiem głównie alkoholizmu i bezrobocia. Panował tam marazm, brakowało głębokich relacji sąsiedzkich, integracji i poczucia wspólnoty, zakorzenienia w tym środowisku.

Wątek rodziny autokratycznej (Ewelina) z dominacją matki (nauczycielka). Generatorem zainteresowań postawami prospołecznymi stały się matka i szkoła (nauczyciele). Ewelina odwołuje się do matki, która w dużym stopniu miała wpływ na jej życie, postrzegając ją jako osobę znaczącą w swojej biografii.

Wątek rodziny bezwładnej, w której brak zainteresowań rodziców działaniami prospołecznymi (Ala). Generatorem zainteresowań postawami prospołecznymi dla Ali stały się szkoła i kościół. W jej narracji odwołanie się do rodziców jako osób znaczących było niezauważalne. W jej biografii własne doświadczenia prospołeczne czerpała ze źródeł pozarodzinnych. Rodzice nie byli dla Ali autorytetami. Nie rozbudzali jej aspiracji czy wręcz ugruntowywali ją w przeświadczeniu o jej niskiej wartości. Brak pomocy ze strony rodziców zmuszał ją do podejmowania samodzielnych decyzji. Zauważamy brak wszelkich motywacji ze strony rodziców do rozwijania jakichkolwiek zainteresowań Ali, a także brak wpływu na jej wybory, m.in. na jej działalność prospołeczną.

\section{PODSUMOWANIE}

Można zauważyć powszechną tendencję do idealizowania wspomnień o swoim domu rodzinnym, o swoim dzieciństwie. Jest to mechanizm tzw. inklinacji pozytywnej, charakteryzujący się przede wszystkim przewagą wartościowania pozytywnego nad wartościowaniem negatywnym. We wspomnieniach eksponuje się wrażenia 
przyjemne, a pomija przykre (Wojciszke 2013, s. 143). Jednak w świetle badań własnych na podstawie wywiadów narracyjnych ta tendencja nie potwierdziła się u wszystkich badanych. $Z$ wywiadów narracyjnych przeprowadzonych $\mathrm{z}$ badanymi osobami można wnioskować, że wspomnieniom towarzyszą wprawdzie uczucia zadowolenia, miłe skojarzenia, ale przede wszystkim są to wspomnienia przepojone smutkiem, żalem, niepokojem, a nawet nieokreślonym lękiem.

Zdolność dzieci do zachowań prospołecznych kształtowana jest pierwotnie w rodzinie poprzez oddziaływania wychowawcze rodziców i właściwe postawy rodzicielskie. Teza ta potwierdziła się częściowo w moich obserwacjach uzyskanych z wywiadów narracyjnych.

Warto zauważyć, że w przedstawionych narracjach odwoływanie się do rodziców jako nośników zachowań prospołecznych występowało tylko u Eweliny, a biografie pozostałych rozmówców były naznaczone doświadczeniami zdobytymi poza kręgiem rodziny (Polski Czerwony Krzyż, duszpasterstwo młodzieżowe, szkolne organizacje wolontarystyczne). W wypowiedziach Doroty i Ali można było zauważyć brak informacji o dziedziczonych w rodzinach postawach prospołecznych, cenienia idei działania dla innych, a także wzorów aktywności społecznej.

Badane osoby pochodzą z różnych kategorii rodzin (autokratyczna i bezwładna). Styl wychowania w takich rodzinach może powodować destabilizację poczucia własnej tożsamości, a w konsekwencji brak stabilnego punktu odniesienia do własnego Ja. Przytoczeni powyżej badani, aby poznać, swoją tożsamość, aby określić swoje miejsce w „świecie”, stosowali różne sposoby. Dla badanych skutecznym sposobem osiągnięcia tego celu było odnalezienie się w działaniach prospołecznych - znaleźli tam to, czego nie otrzymali w domu rodzinnym, np. uznanie, szacunek, podziw, akceptację. Realizacja zadań ponadosobistych otworzyła im drogę do określenia własnej tożsamości i dały poczucie sensu życia.

\section{LITERATURA}

Czerniawska O., 2000, Drogi i bezdroża andragogiki i gerontologii. Łódź, Wydawnictwo WSHE.

Falkowski A., Maruszewski T., Nęcka E., 2018, Procesy poznawcze. W: J.J. Strelau, D. Doliński (red.), Psychologia akademicka. Podręcznik, t.1. Gdańsk, Gdańskie Wydawnictwo Psychologiczne, 339-509.

Izdebska J., 2016, Rodzina. W: K. Chałas, A. Maja (red.), Encyklopedia aksjologii pedagogicznej. Radom, Wydawnictwo Polwen. 
Kawula S., Janke S., 2014, Polimorficzność i komplementarność badań nad współczesną rodziną. W: S. Kawula, J. Brągiel, A. Janke (red.), Pedagogika rodziny. Obszary i panorama problematyki, Toruń, Wydawnictwo Adam Marszałek.

Kułaczkowski J., 2010, Pedagogika rodziny. W: B. Śliwerski (red.), Pedagogika. Subdyscypliny i dziedziny wiedzy o edukacji, t. 4. Gdańsk, Gdańskie Wydawnictwo Psychologiczne, 175-198.

Łobocki M., 2010, Teoria wychowania w zarysie. Kraków, Wydawnictwo Impuls.

Łukaszewski W., 1984, Szanse rozwoju osobowości. Warszawa, Wydawnictwo Książka i Wiedza.

Maruszewski T., 2000, Pamięć autobiograficzna jako podstawa tworzenia doświadczenia indywidualnego. W: J. Strelau (red.), Psychologia. Podręcznik akademicki: Psychologia ogólna, t. 2. Gdańsk, Gdańskie Wydawnictwo Psychologiczne, 165-182.

Maruszewski T., 2017, Psychologia poznania. Umysł i świat. Gdańsk, Gdańskie Wydawnictwo Psychologiczne.

Modrak M., 2016, Pamięć ulepszana. Kraków, Wydawnictwo Impuls.

Plopa M., 2015, Psychologia rodziny. Teoria i badania. Kraków, Wydawnictwo Impuls. Świetochowski W., 2017, Rodzina w ujęciu systemowym. W: I. Janicka, H. Liberska (red.), Psychologia rodziny. Warszawa, Wydawnictwo PWN.

Wojciszke B., 2013, Psychologia społeczna. Warszawa, Wydawnictwo naukowe Scholar.

\title{
RECONSTRUCTION OF THE FAMILY HOUSE'S MEMORY
}

AND SOURCES OF INTEREST IN OVER PERSONAL TASKS

\begin{abstract}
In the article I used fragments of my research studies, prepared on the basis of narrative interviews. I formulated the main research problem in the form of a question: What is the significance of the family in shaping prosocial attitudes among those who perform over-personal tasks? I am also looking for answers to the following questions: Can you find sources of interest in social issues within your and your family biography? Thanks to the use of narrative interviews, I was able to read and understand elements of the subjects reality. I was able to look into the sources and experiences related to the over-personal tasks of the examined persons. Their subjective interpretations of their behaviors, experiences related to different situations, people and events gave a clear picture about the importance of the family in forming a prosocial profile.
\end{abstract}

Keywords: family home, childhood memory, prosociality, over-personal tasks 